\title{
Networked Narratives: Understanding Word-of-Mouth Marketing in Online Communities
}

Word-of-mouth (WOM) marketing - firms' intentional influencing of consumer-to-consumer communications-is an increasingly important technique. Reviewing and synthesizing extant WOM theory, this article shows how marketers employing social media marketing methods face a situation of networked coproduction of narratives. It then presents a study of a marketing campaign in which mobile phones were seeded with prominent bloggers. Eightythree blogs were followed for six months. The findings indicate that this network of communications offers four social media communication strategies-evaluation, embracing, endorsement, and explanation. Each is influenced by character narrative, communications forum, communal norms, and the nature of the marketing promotion. This new narrative model shows that communal WOM does not simply increase or amplify marketing messages; rather, marketing messages and meanings are systematically altered in the process of embedding them. The theory has definite, pragmatic implications for how marketers should plan, target, and leverage WOM and how scholars should understand WOM in a networked world.

Keywords: advertising and promotions, consumer communication, online communities, online consumer behavior, Internet marketing, social media, word of mouth

$\mathbf{W}$ ord-of-mouth marketing (WOMM) is the intentional influencing of consumer-to-consumer communications by professional marketing techniques. Known also as social media marketing, viral marketing, buzz, and guerilla marketing, a plethora of popular books on WOMM have recently been released (e.g., Jaffe 2007; Kelly 2007; Rosen 2009; Sernovitz 2006), and industry associations, such as the Word of Mouth Marketing Association, have grown rapidly and have advocated for the burgeoning new industry. According to recent research, marketers spent more than $\$ 1.54$ billion on WOMM initiatives in 2008, and that amount is expected to rise to $\$ 3$ billion in 2013 (PQ Media 2009).

Marketers and sociologists have recognized the importance of the phenomenon of word of mouth (WOM) conceptualized as a naturally occurring phenomenon-for more than half a century, proposing, for example, that WOM affects the majority of all purchase decisions (Brooks 1957; Dichter 1966). However, these theories and observations about informal, unsolicited WOM were con-

Robert V. Kozinets is Associate Professor of Marketing (e-mail: rkozinets@schulich.yorku.ca), and Sarah J.S. Wilner is a doctoral candidate in Marketing (e-mail: swilner06@ @schulich.yorku.ca), Schulich School of Business, York University. Kristine de Valck is Assistant Professor of Marketing, HEC School of Management, Paris (e-mail: devalck@hec.fr). Andrea C. Wojnicki is Assistant Professor of Marketing, Rotman School of Management, University of Toronto (e-mail: andrea.wojnicki@ rotman. utoronto.ca). This research was partially supported by the first author's Social Sciences and Humanities Research Council of Canada standard research grant (No. 410-2008-2057). Special thanks to the great people at "Buzzablog" who have kindly and patiently shared their data, their time, and their valuable insights. structed in a marketing world untouched by the Internet (Brown, Broderick, and Lee 2007; Dellarocas 2003; Godes et al. 2005; Hennig-Thurau et al. 2004).

The Internet's accessibility, reach, and transparency have empowered marketers who are interested in influencing and monitoring WOM as never before. This article is situated firmly within this new marketing reality. We offer theory that integrates these transformations into the world of WOM. We begin with an overview of the development of WOM theory and its assumptions, placing recent developments into historical context. Building on this framework, we detail our empirical investigation of an online WOMM campaign that engaged consumers who were seeded with a new technology device to generate WOM in their personal blogs. Our findings specify how this marketing process unfolds in the realm of consumer-to-consumer WOM communications. We discuss both theoretical and managerial implications.

We discover and demonstrate four distinct blogger communication strategies in response to the product seeding. These communication strategies are marked by the prominent tension between commercial and communal norms. In addition, they are shaped to fit the represented individual blogger narratives. These communication strategies have specific implications for how marketers should leverage WOMM campaigns, both online and offline.

\section{The Transformation of WOM Theory}

As markets change, marketing theories must also change to accommodate them. In this section, we provide an assumptive frame for this article by briefly reviewing the develop- 
ment of WOM theory and practice, as summarized in Figure 1. Although the overview casts theoretical development as a series of three evolutionary shifts, considerable historical overlap has occurred. All three models currently coexist, and each pertains to different circumstances.

\section{The Organic Interconsumer Influence Model}

Early scholarship established WOM as a significant social force, influencing early marketing thought and practice. For example, Ryan and Gross's (1943) diffusion study suggested that conversations among buyers were more important than marketing communications in influencing adoption (see also Rogers 1962). We refer to the earliest and simplest understanding of consumer WOM as a model of organic interconsumer influence (see Figure 1, Panel A). These interconsumer communications pertain to the exchange of product and brand-related marketing messages and meanings. In this model, WOM is "organic" because it occurs between one consumer and another without direct prompting, influence, or measurement by marketers. It is motivated by a desire to help others, to warn others about poor service, and/or to communicate status (Arndt 1967; Engel, Kegerreis, and Blackwell 1969; Gatignon and Robertson 1986). Views of WOM in this model assume that

FIGURE 1

The Evolution of WOM Theory

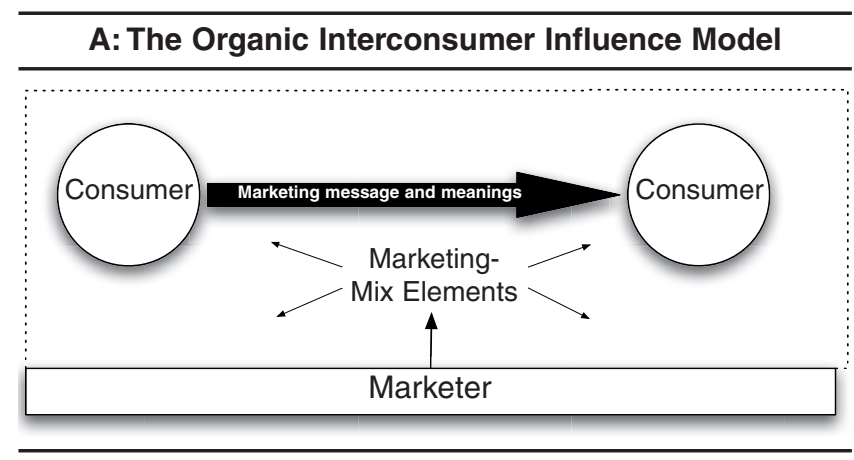

B: The Linear Marketer Influence Model

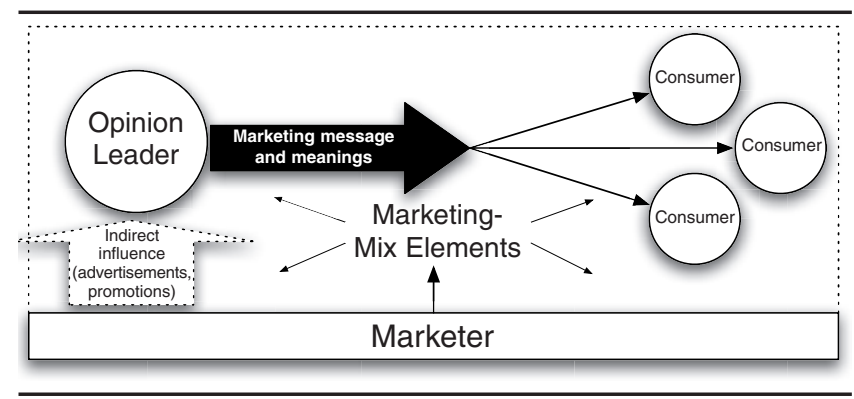

C: The Network Coproduction Model

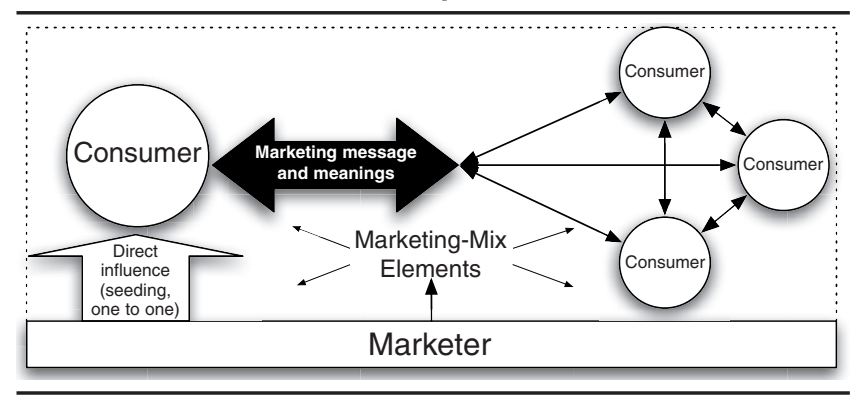

WOM occurs naturally among consumers when marketers perform their job of developing market innovations and performing effective product notification through advertising and promotions (Bass 1969; Whyte 1954).

\section{The Linear Marketer Influence Model}

As marketing scholarship and practice advanced, theories of WOM began to emphasize the importance of particularly influential consumers in the WOM process (e.g., Feick and Price 1987; King and Summers 1976). Accordingly, it was in marketers' interests to identify and attempt to influence these influential, respected, credible, WOM-spreading consumers. This understanding now incorporates an active attempt by the marketer to influence consumer WOM through the use of traditional means, such as advertising and promotions. Therefore, we refer to this stage as a model of linear influence (see Figure 1, Panel B). Occurring during the "cultural engineering" marketing practices of the post-World War II era, which were formed to overcome increasingly resistant buyers (Holt 2002), some consumers were viewed as potential "opinion leaders" who smart marketers could target and influence. Marketers would now be able to work through "the friend who recommends a tried and trusted product" rather than the "salesman who tries to get rid of merchandise" (Dichter 1966, p. 165). Accurate, "realistic information" in marketing was important in these early conceptions because the opinion leader was assumed to transmit marketing messages more or less faithfully, without substantially altering them or having them altered by ongoing communications with other consumers (Brooks 1957; Engel, Kegerreis, and Blackwell 1969; Katz and Lazarsfeld 1955).

\section{The Network Coproduction Model}

The next stage of understanding is the most recent, and though it coincides with the development and recognition of the importance of the Internet, it is not limited to this domain. Marketers have become interested in directly managing WOM activity through targeted one-to-one seeding and communication programs, with the Internet allowing unprecedented new levels of management and measurement of these campaigns and new professional organizations allowing the efficient development and diffusion of WOMM knowledge.

Marketing scholarship has evolved from a transaction orientation to one based on relationships (Vargo and Lusch 2004), with increasing importance placed on the role of consumer networks, groups, and communities (Cova and Cova 2002; Hoffman and Novak 1996; Muñiz and O'Guinn 2001). Consumers are regarded as active coproducers of value and meaning, whose WOM use of marketing communications can be idiosyncratic, creative, and even resistant (Brown, Kozinets, and Sherry 2003; Kozinets 2001; Muñiz and Schau 2005; Thompson and Sinha 2008). Thus, WOM communications are coproduced in consumer networks. There are two distinguishing characteristics of this new model of understanding (see Figure 1, Panel C). First is marketers' use of new tactics and metrics to deliberately and directly target and influence the consumer or opinion 
leader. Second is the acknowledgment that market messages and meanings do not flow unidirectionally but rather are exchanged among members of the consumer network.

Yet, despite awareness of the complexity of these communal relationships, marketers are just beginning to understand the formation, reaction, and effects of communally based marketing promotions. This article's contribution is based on empirical inquiry that attempts to further develop the understanding already captured in the coproduction model and to answer the following three questions: How do communities respond to community-oriented WOMM? What patterns do WOM communicator strategies assume? and Why do they assume these patterns?

\section{Method}

We explore the lived phenomenon of WOMM in a naturalistic context. Our research approach is qualitative and aims to generate scientific propositions about this new phenomenon that can be subject to further testing and verification. Our investigation focuses on a blog-based campaign in six North American cities. The blog context is highly relevant to our study because blogs have been increasingly popular sites of WOMM campaigns (Kelly 2007; Rettberg 2008; Sernovitz 2006). Estimates by eMarketer placed U.S. blog advertising at \$283 million in 2007 and suggest that $50 \%$ of all Internet users are regular blog readers, a figure the firm predicts to rise to $67 \%$ by 2012 (Kutchera 2008). Furthermore, 2006 European surveys indicate that blogs "are second only to newspapers as a trusted information source" (Brown, Broderick, and Lee 2007, p. 16).

We studied a "seeding" campaign — that is, a campaign in which the product is placed among influential consumers so that they can communicate favorably about it to other consumers (see Balter 2005). The campaign was conducted by one of the pioneer North American WOMM firms ("Buzzablog") for a major global technology manufacturer ("MobiTech"). 1 The campaign, designed to promote a new camera-equipped mobile phone (the "MobiTech 3839"), seeded the phone as well as accessories and a usage tutorial with 90 bloggers who had previously been contacted by e-mail and telephone and screened for consideration. Influential bloggers were chosen on the basis of the lifestylerelated relevance of their blog content and blog traffic of at least 400 unique visitors per day. Although participants were encouraged to blog about the phone, the campaign did not require them to do so. Most of the products were seeded in two large cities with a combined population of more than seven million people. The campaign yielded significant activity. Of the selected bloggers, $84 \%$ mentioned the phone in their blog. In an interview with the Buzzablog director who supervised the campaign, he remarked on its success:

I'd say we were pleasantly surprised how many of the influencers that we engaged actually participated in some

\footnotetext{
${ }^{1}$ Although we realize the limitations of pseudonyms in the age of the Internet search engine, we follow convention and use pseudonyms for the names of community participants, as well as the name of the technology company, its product, and the marketing agency.
}

way along the lines I was just describing, by creating content online about the product [recommending it and inspiring others to product purchase].... We achieved what we wanted to in terms of influencers talking about the MobiTech brand and about this product to a very high degree. On the whole, the commentary about the product was very positive. So people who were talking about the properties of the product were very positive on it. And we know from follow-up surveys with all of these influencers that we had a significant number of sales that were actually influenced by these influencers, as a result of recommending the product. So, in all those ways, we got the results that we had hoped for and that MobiTech had hoped for. (personal communication, March 28, 2009)

However, if marketers want to fully grasp the effects of their WOMM strategies, it is necessary to look beyond measures of communication frequency or valence and consider its content. To do this, we conducted an online ethnography, or netnography (Kozinets 2002). We followed Kozinets's (2007) recent recommendations for adapting the netnographic technique to blog content. Although we observed these blogs without posting to them, we participated in several discussions with Buzzablog about the campaign. We also met to discuss and analyze our ongoing individual participation in online communities, as well as our readership of, participation in, and (in one case) authorship of blogs. Although we did not participate directly in the focal blogs, our analysis reflects the participative component that is a hallmark of interpretive depth in both ethnography and netnography.

Of the 90 bloggers who were seeded in the campaign, we collected data from the 83 whose blogs remained accessible throughout the entire length of this study. These bloggers ranged in age from 22 years to 45 years at the initial time of the campaign, and 59\% were male. They also had a range of occupations, including photographers, designers, writers, programmers, consultants, and administrative personnel.

To establish a baseline reading of the blogs' content, we collected blog entries beginning three months before the product seeding. We collected data from the start of the campaign until immediately after it to establish initial reactions. We continued to follow the bloggers and their postings for a period of approximately three months after the WOMM campaign. This longitudinal approach allows for analytic depth and enriches the effort to develop relevant theory. Total downloaded data amounted to more than 4300 single-spaced pages of 12-point-font text, representing approximately 1,376,000 words and 6722 postings, as well as significant additional amounts of visual and audiovisual data. The total number of postings in which the bloggers wrote about the phone or the campaign amounts to 220. Our data set contains approximately 700 comments of blog readers who responded to the WOMM campaign.

We sorted and classified all postings into individual blogger files, and we categorized the files as before, during, and after the WOMM campaign. We coded the data into initial categories, analyzing them for themes relevant to our investigation of WOMM. Through group comparison and multiple rounds of in-person discussion, a grounded, metaphorical, and hermeneutic interpretation emerged. We identified recurrent social and cultural tendencies within the 
data and used the constant comparative method to generate insights. We tested and verified our theory in this way, looking for disconfirming cases and altering our theory in multiple rounds of analysis. In this second step, unexpected findings led us to develop our network coproduction model of WOM, identifying our main theoretical implications. Our overall approach is in keeping with the precepts of mainstream qualitative data analysis and interpretation (e.g., Thompson 1997).

Although our theory development is based on the entire data set encompassing all 83 bloggers, for data presentation, we offer a more nuanced recounting of a greatly reduced subset. The sections that follow focus on the individual stories of 4 bloggers whose responses to the campaign are representative of our findings across the entire set. Samples of additional blogger responses, which we present subsequently, underscore the general nature of our findings.

\section{WOMM in Online Communities}

Our data analysis and interpretation reveal that WOMM is part of a complex cultural process that nonetheless follows an ascertainable pattern. On the surface, WOMM that attempts to direct the discourses of bloggers may seem to have many similarities with the use of public relations or other forms of paid promotion. However, because of a range of novel contextual and institutional elements that do not generally exist in the professional journalistic or advertising relationship, the WOMM campaign is injected into less established, less defined, and more complex cultural relationships. These elements encompass and are related to the networked coproduction of marketing-related communications. Although we present these proposed elements before elaborating our findings, we derived them from an inductive, ground-up data analysis process. Figure 2 captures the range of elements and their interactions.

The WOM communication that is of interest to marketers - a market-based message and its associated meanings, as well as its reception by an intended audience-is influenced by four important factors. First, it is affected by its placement within what we more broadly term communicator "character narratives," or enduring personal stories or accounts that we may understand as being related to particular expressed character types. Narratives vary, but there are distinct archetypal patterns in how people offer perspectives that unfold over time. For example, a blogger may self-identify with the character of a loving mom, which results in a narrative that stresses kindness, helpfulness, and caring. Others present a professional, critical, or clinical character, as might be seen in review blogs. Still others exemplify engaged community member types (e.g., political bloggers, citizen journalists). Psychological guides to personality, such as the Myers-Briggs type indicators, might usefully be employed to further specify the common components of these created character types.

Second, WOM communications take place while embedded in a particular forum. The forum under investigation in the current research is the blog, but other WOM contexts might include dinner parties, bars, schools, or social networking Web sites. There are different types of blog forums. We identify and examine personal life crisis, relationship, technical, and mommy forums. Sports, health, fashion, celebrity, and news are other examples of forum topics.

Third, the WOM communication is affected by communal norms that govern the expression, transmission, and reception of a message and its meanings. These norms would vary by the size of the community, the average age of community members, their interests, their lifestyles, their ethnic orientation, social class, and extent of shared history, among other factors.

Fourth, the message and meanings of the WOM communication are affected by the promotional characteristics of the WOMM campaign and related promotions, such as the type of product or service, the product's brand equity and the objectives, terms, hard-sell nature, and humorousness of the campaign.

In the network of WOM communications, these four elements work in concert to alter the nature of the WOMM message and its associated meanings. They influence its expression. They transform it, as we explain subsequently, from a commercial promotion to communally valuable information. Character type, blog forum, and communal norms affect the narratives and influence the audience attracted to the blog and members' response to its content. Pertinent to our study, the four elements also influence the manifestation and reception of WOMM messages. Following these four elements, we gain an understanding about the forces that shape WOM in the complex manner depicted by the network coproduction model. In the remainder of this article, we explore the nature and implication of these networks of narratives.

We recount in some detail the character narratives and types, communications forums, and communal orientation and reception of four blogs from our data set on the MobiTech-Buzzablog WOMM campaign. For confidentiality, we have given the bloggers the pseudonyms "Frank," "Alicia," "Carrie," and "Judith." We offer each profile in depth to illustrate the complexity of the manifest phenomenon, which encompasses WOM content and the communal interactions resulting from the WOMM campaign. Each of these four blogs exemplifies a particular narrative strategy that is significant to marketing research and practice.

\section{Frank's Blog: Seeking Social Connection and Offering Explanation}

Character narrative, forum, and communal orientation. According to his blog, Frank is a 27-year-old former broadcast engineer in the midst of several significant life transitions. He recently married and moved from his hometown in the Midwest to his wife's hometown in a major Northwestern city. Frank's blog, a hybrid personal-technology forum, becomes a way of "sorting out our new lives together." Frank had been unemployed for almost two years after moving and writes about finding his way around-and eventually into-new communities in the city.

As expressed on his blog, Frank's character narrative reveals goals of connecting with people and fitting in, as well as a love of media, particularly radio. The two intertwine in his current project of settling into a new commu- 
FIGURE 2

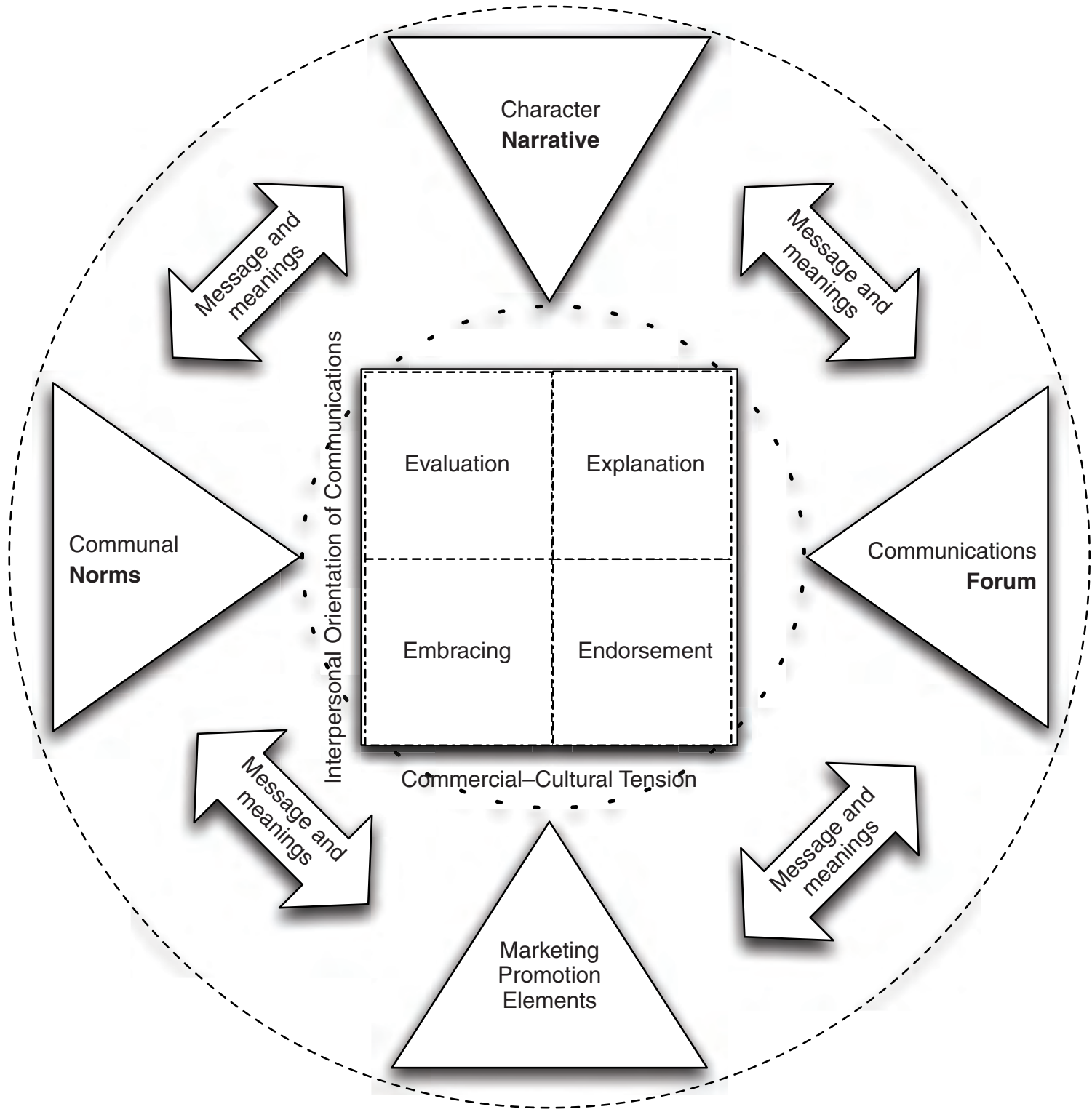

Exogenous Social, Cultural, and Psychological Elements

nity as he uses media (blogging, podcasting, and photography) as a vehicle to gain entry and status into the local network of technophiles. For example, Frank uses his wife's (she is also a blogger seeded in the phone campaign) membership in "Metblogs," a community-based club of bloggers, and his common interest in blogging and technology to forge relationships in his adopted city. This use of online communities to forge offline relationships is common (USC Annenberg School 2008). Over time, Frank begins attending in-person Metblog "meet ups" and writes:

[Through blogging], I have been able to meet some really great people and develop friendships that are building into a community like I have never experienced before. We all do our own thing and when you actually meetup [sic], you already have something to talk about and expand the back story on. In turn, those experiences can lead to more material to write about later. It's an intriguing circle. (blog post June 12, 2007)

The WOMM campaign. Frank's participation in the WOMM campaign comes relatively soon after he begins to adjust to his new city and provides a vehicle for building affiliation. Aside from its functional and economic value, the WOMM campaign has what Cova (1997) terms "linking value," facilitating Frank's integration into his new community. For example, the first of ten postings that refer to the seeded product is titled, "I'm one of those Buzzablog lucky ones" (blog post July 16, 2006), underscoring the affiliation and connection emphasized in his blog. Note that Frank identifies campaign participants with the name of the 
WOMM firm rather than the product, minimizing the importance of the phone itself as an object of focus and value.

Having asserted membership in the local blogging community by identifying himself as "one of them," when Frank experiences ambivalence about participating in the WOMM campaign, it is not surprising that he then seeks explicit affirmation that he is conforming to communal norms. Frank interviews several members of "Metblogs" for a podcast and, in particular, confers with a member ("Brian") who has also received a MobiTech phone in this WOMM campaign. The tone of the podcast ranges from humorous to ironic to uncomfortable:

Frank: I was going to ask you, I just saw you pull your nice MobiTech out there ...

Brian: [interrupting] the following is a paid endorsement!

Frank: [feigning surprise] you're being paid for this?

Brian: Well, not being paid, but bribed for certain, umm.... MobiTech, through their viral marketing partner Buzzablog and in association with [wireless mobile company], have basically had sort of an aid shipment of phones for bloggers and it's a great concept. Basically, they send phones to bloggers in the hopes that they'll bribe them, er, in the hopes that the bloggers will talk about the phones on their websites. All I can say is that I think this is an excellent marketing proposition; I'm really hoping that Audi gets behind this idea as well, 'cause A3 2.8 S-Line, I am all there, right? But yeah, it's a perfectly acceptable phone, I don't want to give a capsule review,... [opines on phone and future technology].

Frank: Right (laughing). And I too was contacted by the same viral company.... What do you feel about the whole process in general? Do you feel like you were spammed into this and also, how do you feel about doing this on your blog, because obviously I'm doing it on my podcast, so I don't have too much of a problem with this, but....

Brian: I want to make this entirely clear right now. Attention corporate marketers: if you want to give me $\$ 300-\$ 500$ worth of free stuff, my number is: [later scrambled out in editing]. I will take your call at any time of the day. I can be bought and I am relatively cheap.... Maybe I should just put my e-mail account in there instead. Attention marketers: my e-mail address is [address]. I can be bought and I'm cheap!

Frank: Especially if you have any MP3 recording equipment, that's what I'd like to see. Please. Thank you. [Restates URL address for his podcast so donors can find him.]

Note that Frank joins his interviewee in speaking directly to marketers. This is an important action, for in that moment, not only has he moved from citizen journalist to fellow blogger, but he has also publicly considered the potential conflict triggered by participation in the campaign and received approbation from his referent community. The podcast audio also indicated that other people were gathered around, laughing, and calling out comments or suggestions.
It is noteworthy that Brian uses the word "bribe" (twice) as well as the phrase "I can be bought." In addition to highlighting and thus, in some sense, discharging moral conflict, the term confirms the significance of his awareness that he is simultaneously a target and a marketer. In the discussion of the "price" of receiving a free phone-framed by a pop culture reference to infomercials ("the following is a paid endorsement") — and use of the ethically loaded term "bribe" to surface the tension, Brian signals that he is not naive about the objective of the WOMM campaign and that he wants his online and in-person audience to read his comments as infused with irony. Outing the marketers' motivation and even inviting more of the same, he confidently announces his knowledge of persuasion tactics and simultaneously asserts agency in accepting them (e.g., Friestad and Wright 1994).

Congruent with his narrative theme of gaining acceptance, Frank uses his participation in the WOMM campaign as a form of social capital. A few days after making initial remarks about the phone, Frank leverages the podcast as evidence that he is now not only friendly with other, higherstatus bloggers but also performing a service for the wider technical blogging community. In a post forthrightly titled "Addressing the Buzzablog Issue," Frank confronts the tension, in part by demonstrating his awareness of the mechanics of WOMM:

So how do I feel about doing this? There is a part of my soul that feels like there is some selling out going on here, but I like being someone who can be a part of reviewing a product and actually do it with some honesty.... [I]t's not the absolutely, greatest phone that beats out anything else out there that you could buy. It's also far from being the worst.... Word of mouth. That's what this is. It's not overpaid actors telling you that they use this phone; it's the best and you should, too. I'm just a guy who blogs among the community of other bloggers with connections to the city of [name].... In fact, did you listen to the last episode of my podcast? I had a chance to meet a fellow blogger who got the same deal and it was quite possibly some of the best content to come from the podcast yet, even if it did promote a product. But ask yourself, would you rather listen to us wise crack about this MobiTech or have some high paid actor or actress speak at you? It feels good to know that there are people out there trying to break from the static model mass media uses for advertising. (blog post July 26, 2006)

Frank's posting reveals a constant tacking between ethical perspectives as he tries to argue for his legitimacy and concern for the community, emphasizing his "honesty" in both praising and criticizing the phone. The post expresses discomfort at "selling out" and guilt over collusion with marketers. Frank tries to impression manage his role, framing himself not as a marketer's puppet or an "overpaid actor," but instead as a bona fide member of his adopted community ("I'm just a guy who blogs among the community of other bloggers"). Actively seeking to persuade his audience that his participation in the WOMM campaign not only was worthy of communal sanction but also could be beneficial, Frank presents himself as more faithful to the community's interests than to those of the marketers. The post inspires two positive comments, both from community 
members affirming his position, evidence that he has integrated his participation in the campaign in a way that is consonant with both his narrative and his forum's wider communal norms. There are no negative comments on Frank's WOMM campaign-related posts, and comments indicate a willingness to continue talking about the phone.

Although he remains critical of some of its features, Frank's blog continues to mention the phone for longer than most of the bloggers in the data set; the last posting mentioning either the phone or the campaign occurred approximately seven months after the initial post (July 16, 2006-February 23, 2007). In later posts, Frank reveals his love of the Apple brand. When he learns that a fellow blogger owns an iPhone, he conducts an interview with the owner and posts a product review under a post reverently titled "I touched an iPhone," while his own MobiTech phone is presented as a weak competitor: "All the [iPod] features make sense, applications work like I expect them to, and you quickly forget that you [are] tapping a flat surface, opposed to the numerous buttons that exist on my MobiTech 3839" (blog post August 20, 2007). The transient project connected with the WOMM campaign moves from one phone to another, while the more persistent narrative of connecting with others remains strongly expressed throughout the blog. Many bloggers adopt a similar discursive strategy of explaining the WOMM campaign and their involvement in it. For example, "Sammy," a recent university graduate and long-time blogger, writes eloquently on the importance of technology and community. A typically reflective post finds him ruminating on identity and audience: "The construction of identity through technology is also no longer a personal endeavor; in fact, the strengthening of one's identity now comes through the sharing of ideas, thoughts, and practices across boundaries that are easily crossed in a world of networked communications" (blog post December 28, 2005). When Sammy, not yet having received the phone or blogged about the Buzzablog campaign, is quoted in a national newspaper story about his participation, he unflinchingly meets the exposure with a post titled "Free Stuff and Blogging: Not an Ethical Quandary" (blog post July 2, 2006) that explains his perspective on the WOMM campaign. Table 1 summarizes details associated with Sammy's blog and others who share common themes with our four representative bloggers.

\section{Alicia's Blog: Honesty and Humility Meets Marketing Intent}

Character narrative, forum, and communal orientation. Alicia is a 33-year-old, stay-at-home mother of two young daughters and a freelance writer living with her partner, a musician. She has maintained an online journal of some sort since 1996 and classifies the current format of her blog as a "mommyblog" (blog's "About" page, Spring 2007). Alicia often mentions that her blog is personal and serves as a repository of her family memories, disclosing actual names and photographs of family members as well as details such as the births of her daughters. Her character narrative represents Alicia as a loving mother who frequently does not manage to live up to her own expectations. She is humorous but often self-deprecating. The narrative reflects values of truthfulness, humility, simplicity, and caring, as well as a goal of gaining genuine human contact during her rather isolated life stage of being a stay-at-home mom.

Alicia's blog entries attract an average of four comments daily from a loyal group, many asking Alicia how to deal with particular parenting issues. In her answers, Alicia does not depict herself as an authority; rather, she discounts her talents as a mother, giving credit to her kids or the circumstances. She is careful not to make judgments about parental issues, such as cosleeping and breastfeeding. "Being honest online about the real trials and tribulations of parenting and especially motherhood because of the ridiculous expectations (both from others and the self-imposed expectations), means that we suddenly feel just a little less isolated" (blog post June 13, 2006, parentheses in original).

The WOMM campaign. When Alicia is contacted about the WOMM campaign, her first posting exemplifies her life theme of humility through her expression of disbelief: "[They] offered me a free cell phone in exchange to [do] nothing more complicated than promising to use it and to maybe write about it. Honestly? I thought it was a scam" (blog post August 4, 2006). In her first blog entry about the phone itself, titled "Free stuff rocks," Alicia discloses the campaign details, who contacted her, the message, and her obligations:

You have to be someone who uses photos and video on your blog, have approximately $400+$ visits per day and be between the ages of 22 and $35 \ldots .$. I had no obligations. I didn't have to use the phone for a specific amount of time if I didn't want to. I didn't have to buy a particular plan. I also didn't have to be positive in my reviews. I can be honest and if I hate the phone altogether, I can say that. (blog post August 4, 2006)

When describing participation requirements, Alicia uses the pronoun "you" instead of "I," implying to her audience that they too may be eligible. Generously sharing involvement, she offers to connect anyone who meets the criteria or "is close enough to give a shot anyway" (blog post August 4, 2006) with Buzzablog. Consistent with her blog's leitmotifs of humility, caring, and honesty, Alicia emphasizes the nonobligatory nature of the agreement.

The subsequent text of the blog is a marketer's ideal testimonial. Alicia explicitly expresses her love of the phone and enthusiastically shares her amazement about its functionality. She uploads pictures she has taken with the phone, and her word choice shows that she feels both spoiled with the costly, impressive phone and proud and modern to be able to manage such a high-technology device: "Dude, I'm practically moblogging" (blog post August 4, 2006). She has some minor complaints (lack of faceplate) but uses this to show that the MobiTech phone is precious to her- "I'm so afraid of scratching its ginormous LCD" (ibid)—as well as signal that she is giving a thorough and impartial review.

Alicia's second, glorifying post about the phone yields negative comments from her readers, who accuse her of not actually receiving the phone for free and of being boastful. In response, the narrative shifts to a defensive tone. Two 
TABLE 1

Supplementary Blogger Data

\begin{tabular}{l} 
Evaluation \\
$\begin{array}{c}\text { Orientation: Communal } \\
\text { Tension: Implicit }\end{array}$ \\
\hline Joseph: If any of you have \\
noticed the flickr stream now \\
on this page to the right, the \\
pictures there were taken \\
from a Mobitech 3839 that I \\
just received yesterday. [does \\
not mention how he received \\
the phone] ... I have to say \\
that my first impressions with \\
this device are pretty good so \\
far. I've been able to snap \\
pictures and some decent \\
video, play mp3's, have fun \\
with Bluetooth.... I've only \\
spent a day with it so far, but \\
there are some tiny things I \\
have to nitpick about.... Well, \\
I look forward to messing \\
around with this thing and \\
checking out all the possibili- \\
ties. l'll keep you posted with \\
more in-depth reviews and \\
posts about cool things you \\
can do with this phone. \\
Cheers!
\end{tabular}

(blog post July 7, 2006)
Explanation

Orientation: Communal Tension: Explicit

Randy: [post title: “I won't be Mobitech's Bitch"] This is cool: Mobitech's going to be sending me a fancy free (not fancy-free) cell phone soon, because I have the POWER of BLOGGING at my fingertips. They called, got my name from somewhere I guess and a nice woman asked me a bunch of questions about how often I blog and what about and do I know how to use a telephone and so forth.... [M]e and 44 other people ... will be getting a MobiTech 3839 multimedia smart phone.... Don't worry, I won't fill up the blog with all sorts of shilling, toadying, sycophantic things about Mobitech, even though they're being so nice to me. No, for that to happen, they'd need to send me to [Mobitech company headquarters]. Perhaps in August? Hello? (blog post June 23, 2006)

Jasper: [first of an extensive, multipart review] I got a new cellphone and I'm going to talk about it to death. This is the first part of a five part series and I think this is the best review you'll find the MobiTech 3839 because unlike all those other gadget/phone reviewers, I will be using this phone every day for the next two years (unless some other company wants to give me one for free). (blog post July 30, 2006)

\section{Sammy: People have been asking about ... the whole} free phone gig and how I can reconcile my code of ethics with blogging about products I receive for free.... I just can't seem to see the ethical quandary here: I'm not being forced to say good things about a product, or anything at all.... Bloggers do have the potential to sway public opinion (which is why I think Buzzablog is working in a particularly genius manner for the Mobitech promotion.... Accepting the new Mobitech is not an ethical quandary at all. It is instead a reflection of a very smart strategy by Buzzablog. (blog post July 2, 2006)

\section{Embracing}

Orientation: Individual

Tension: Implicit

Franklin: I went to see The Corporation;... it was an interesting, thought provoking movie. But one section resonated with me in ways I'm sure the movie's makers did not intend. There was a long segment about how advertisers were finding insidious ways to get their product into your earshot.... And rather than be disturbed by the insidious (though some might say: creative) paths corporations were taking to get their products into the public consciousness, my reaction was quite different. My first thought was: gee, how do I get myself a piece of that action?... I've been blogging for four and a half years and I had to wonder, where was my free stuff? When was Apple going to contact me and ask me to test out their new black MacBook? (hint, Apple, hint!). Until today. (blog post July 11, 2006)

\section{Svetlana: [post title: "Will} Blog for Phones"] As a good marketing whore, because l've so had enough to give and never receive anything in return, you will see me posting pictures taken with this phone, I may even do some video, but don't you think that I am going to become the next Paris Hilton.

(blog post June 28, 2006)
Troy: [response to reader comment about the film The Corporation] Seen it? I saw it opening night in Ottawa and my friends have the extended DVD. Yup. Crazy marketing. But I needed a cellphone. Mine was dying, so the timing is perfect. Either way, I write about RAID Cards ... so writing about anything tech related that I own is normal for me. But yeah, it's called guerilla marketing or something.... So where have you been? (blog post August 24, 2006)
Shane: Mobitech is doing a motion giving their phones out to bloggers in the hopes they'll spread the word online and talking to friends, posting the cellphone. I'm thankful I out perfectly as I was just starting to look for a new phone as well. It's all voluntracts. I don't have to do any of this, but since I usually ways, I have no problem writing a voluntary review as and gear for free. And l'll even be impartial about it. (blog post July 10, 2006) 
weeks later, a post entitled "For the Record" attempts to defend her actions as a WOM marketer:

For people who like to use information off my website against me, you should note that the camera phone I own was given to me for free from Buzzablog, a buzz marketing company in exchange for promising to use the different features and to review it. I DID NOT BUY THE PHONE. The last time I turned my pockets inside out or shook my wallet upside down, $\$ 350+$ did not fall out. I would not have bought the phone because it's about $\$ 345$ out of my budget. (blog post August 20, 2006)

In an effort to defend and authenticate her claims about the campaign, Alicia's post references other bloggers who have also received the phone from Buzzablog. She links to another blogger's entry with the requirements for participation and stresses her "luck" in meeting all the necessary requirements (blog post August 20, 2006). A week later, Alicia posts a couple of pictures and videos that she has taken with the MobiTech phone, remarking sarcastically, "I'd also like to re-iterate that they were taken with my MobiTech cameraphone, which I got for free from Buzzablog, lest anyone get their knickers in a knot again over the false idea that I am rolling around naked in my huge piles of money" (blog post August 20, 2006).

Notably, these negative reactions are unaccounted for by the classic diffusion model (Bass 1969; Rogers 1962) and its more recent variants (e.g., Balter 2005), which consider lower-status people prone to imitate the consumption of those of higher status. Instead of inspiring imitation, this campaign provokes a negative response from some of Alicia's readers.

Key to understanding the cause of this friction is its relationship to her character narrative, blog forum, and its communal norms. Alicia's narrative is about family, and accordingly, her blog constantly reiterates the common bonds, through parental struggles, between herself and her readers. In contrast, Frank's blog is about technology, his position is that of an expert, and his narrative theme is about connecting. Although Alicia's character type stresses humility, transparency, and egalitarianism, her sudden status change to that of influencer-signaled by her selection for the WOMM campaign-grants her implicitly superior social standing and appears to change her role from empathetic community member to valorized outsider. After the ensuing outcry, her blog never again mentions the MobiTech phone. However, she continues to list it on her Flickr page as one of the devices with which she takes pictures.

Shortly after the MobiTech WOMM campaign, Alicia's blog becomes a for-profit forum as she begins accepting assignments for Payperpost. Payperpost (www.payperpost. com) is a company that pays bloggers to write postings for advertisers. In an entry stressing her integrity, Alicia's posting explains her decision to her readers: "A lot of people have been negative about it but I think it's great, honestly. I only choose to review things that I genuinely agree with or appreciate. As a result, I think it's possible to write for Payperpost while still maintaining your integrity as a blogger" (blog post November 14, 2006). She states that her motivation is simply to earn some extra pocket money. This shift in blog forum implies that Alicia's experience with
WOMM may have awakened her to the blog's moneymaking potential.

Later, Alicia also responds in another posting to negative comments that she received in private e-mail messages (i.e., not posted on the blog). Her rationale combines an assertion of her honesty-"I truly only write about things that I have an interest in or can support"-with a description of her need for money: "It has helped to pay a little bill here or a little bill there and for that I am grateful and happy to do it" (blog post March 5, 2007). She finishes by telling her readers to sign up, a symbolic offering of her newfound wealth, similar to the gesture she previously made with the Buzzablog campaign. However, most of her readers are unlikely to be high-traffic bloggers like her and therefore would not qualify for assignments from Payperpost.

The negative responses continue, some simply calling for her to "Stop it" (blog comment May 24, 2007). The negative reactions subside after Alicia initiates a new type of forum: a review blog that she describes as "an accompaniment to my main blog so that I [can] share reviews of products, books, and services" (Alicia's review blog "About" page, July 2, 2007). This separate blog-within-ablog contains only fully disclosed paid endorsements. In general, the few comments that these reviews elicit come from readers who are also supportive of the product. However, most readers refrain from commenting on her sponsored postings, indicating that Alicia's new role of semimarketer is accepted, or at least tolerated, when constrained to a separate, specially partitioned Web site.

\section{Carrie's Blog: Mocking, Exhibitionism, and Embracing Commercialism}

Character narrative, forum, and communal orientation. According to the blog, which she started in 2003, Carrie is a 23-year-old cultural studies student who lives with her parents. She takes an interim job as a personal assistant in an engineering firm and, around the same time, becomes involved in a serious relationship. Her blog, in which she writes wittily about her current goals and activities, such as dating, finding a serious relationship, and finding a job, presents itself as a coming-of-age diary. Its self-satisfied, selfcentered narrative focuses on dating, drinking, and dressing and is illustrated with numerous pictures exhibiting Carrie in sexy clothing and flirty poses. Carrie's blog exposes her propensity for exhibitionism and fits into the common productions of a narcissistic MySpace/Facebook generation that have been chronicled in the popular press (see Gould 2008; Nussbaum 2004). Researchers have hypothesized that the Internet fuels this attention-seeking exhibitionism to new levels (Holbrook 2001).

Yet, despite the blog's ostensible exhibitionism, much is cloaked. The blog reveals only fragments of Carrie's daily routine, and the people around Carrie are never mentioned by name, but rather by relationship, as in "my sister" or "my boyfriend." Unlike Alicia's blog, Carrie's does not confide in its audience. Instead, it entertains them by showing off, by judging people, or by making fun of others. The blog is full of detailed, deriding descriptions of others' behaviors, opinions, clothing, and lives, but its pet topic is relationships; "I thought I should share one of my most favorite 
pastimes: Mocking the pictures and comments on Facebook's various 'Being Engaged Rocks!' groups" (blog post July 6, 2007).

Carrie's life theme is that of seeking attention, and this implicit narrative runs throughout her blog, which is audienced by eager voyeurs who enjoy her biting wit. With her frank observations about the sex lives of twenty-somethings in the style of Sex and the City's fictional character Carrie Bradshaw, blogger Carrie attracts the attention of the traditional media. She is quoted in the local press and provides advice on a radio program and television show as a "relationship and dating expert." The blog gains her a loyal, eclectic audience that leaves 10-25 comments per post. Whereas Alicia's blog exchanges with readers are usually friendly, the comments on Carrie's blog tend to echo her mocking tone. Although it is typical for her audience to respond to her boasts with sarcasm, when Carrie receives more exposure in the traditional media, her blog increasingly attracts an (anonymous) audience that leaves vicious comments. "Honestly, if you weren't constantly judging others, you wouldn't have much to say. Right down to the shoes that people wear on the bus, you are constantly criticizing and judging others. Can't you think of more important things to talk about than how much better/prettier/ smarter you THINK you are than other people?" (blog comment November 11, 2006).

The WOMM campaign. Carrie's blog does not accept advertising, and its narrative does not contain many references to brands. Its initial entry about the WOMM campaign seems both delighted and self-congratulatory:

The perks of being addicted to maintaining a tiny piece of the internet come in many forms-from getting free things to being contacted by both celebrities and the people who make celebrities to getting dates from something I've written-yes, this site has created a lot of opportunities.... I know that I've been totally lacking on photo content recently, but that's simply because I haven't had a camera. MobiTech decided to fix that and tomorrow I am being given a brand new beautiful 3839 phone as well as a whole bunch of additional accessories and features. This means that the next time I am judging weird people on the subway or being crazy at the bar, everything will be camera-captured or even videotaped and instantly uploaded to this blog with hilarious commentary. It's going to be positively thrilling! (blog post August 3, 2006)

Note that Carrie does not provide her readers with any details about the WOMM campaign. Unlike Frank and Alicia, who provided those details and stated that they were lucky to have been selected, Carrie's narrative frames the free gift as an entitlement flowing from her successful, high-status, attention-seeking activities. She has become a celebrity and thus deserves celebrity "schwag." What is mentioned about the phone is linked to her blogging activity ("I've been lacking on photo content") rather than the phone or the campaign. Carrie receives mostly positive comments from her loyal readers, who congratulate her for her success. A few days later, Carrie's blog contains another post about the phone. She adopts her usual mocking tone, but this time appraising herself: She loves the phone but also makes fun of herself for loving it so much.
So now I have this phone from MobiTech, which I was given, free-of-charge, for the purpose of promoting among my social network. At first I was a tad apprehensive to the whole idea-being trendy is one thing; secretly branding products as a tastemaker is borderline selling-out. But once the phone was placed in my hand I became instantly transfixed and my doubt was replaced with: "How could anyone not want this phone!?" as well as: "It's soooo awesome, it's pretty much the best celly I have ever had! The best cell I have ever seen!" and also: "Everyone LOOK at my new phone, look look look at everything it does!" I am almost ashamed at myself for the level of eagerness I have towards talking about the phone. But I have decided that trend marketing is the easiest form of marketing, given the right product and people involved, with me and the MobiTech being a prime example. I rarely initiate conversations about the phone, but when they start, oh then I go into celly-love gushing mode, where I blab endlessly about things like being able to watch videos on it and adjusting the white-balance on my zoom-lens camera. This all sounds like a carefully crafted product placement, doesn't it? I told you, I'm an advertiser's dream: my talking about the MobiTech is not done for contractual obligations or to please them; it's motivated by my overwhelming need to brag about having received THEBEST PHONEEVER for free. (Which, I now realize, does end up pleasing MobiTech. And so it goes...) So while I'm at it, let's air out some other products I am currently infatuated with, simply because they're trendy and up to par with my lifestyle. You know, other things I would wax poetic about, samples or not. (hint, hint?) (blog post August 9, 2006)

Although this narrative acknowledges the marketerconsumer tension, it is raised in a tongue-in-cheek manner, suggesting that concerns with "selling out" are instantly overcome after she receives and experiences the phone. She jokes that she is "an advertiser's dream." Congruent with her character type and life project, Carrie chooses words that are related to relationships and sexuality ("celly-love gushing mode," "infatuation"). She portrays herself as a promiscuous consumer, selling a "lifestyle" and "promoting [products] among my social network," flitting from "It" product to "It" product and happy to engage in synthetic WOM "given the right product and people involved." This remark is noteworthy because it suggests to readers that the product is of such high quality that she cannot help but extol its virtues. It also suggests that she is one of "the right people," a worthy tastemaker. In the same post, Carrie lists other products (rosé wine, skinny jeans, a designer bag) that she is happy to blog about because they are "at par with [her] lifestyle." She solicits marketers directly ("hint, hint"), showcasing and suggesting her continuing skill as a WOM marketer and also tells her audience that she is "infatuated" by products other than the MobiTech phone, the subject of the WOMM campaign.

However, Carrie's blog posts do not provide readers with many details about the phone. She breezily mentions that she received "a bunch of accessories," that she can "watch videos," and that she can "adjust the white-balance on the zoom-camera." However, these are the only specific reasons she gives to explain why she loves the phone so much. The posts are predominantly about having received 
a cool new phone for free, leading to a range of critical comments:

Secretly ... plotting your demise/I wanna devise a viral marketing campaign/To bring dire straits to your ability for discerning choice/Bolster corporations with a mild blogger prose/Trash your consumer awareness and revert you to a walking wallet. (blog comment August 9, 2006)

I used to love the innocence of your blogs and the wittiness you had of the world around you and I always thought you were really cute, well I still do. Your earlier western day blogs can be compared to artist's first record or two but sooner or later they sell out and their material goes downhill.... Is this what is happening? (blog comment August 9, 2006)

That's a nice Christmas list Carrie, but don't forget that we come here to get a peek at the life of a cute privileged woman and not to read advertisements,... regardless of whether or not the company that now owns your ass has induced your superficial blurbs. (blog comment August 10, 2006)

Apparently, Carrie violates a communal norm by so ardently promoting the product on her usually critical and biting blog. As the comments evidence, her endorsement is viewed as a lack of "discerning choice" and "trashing" of her critical "consumer awareness" faculties. Carrie is pictured as having lost her "innocence," being "owned" by a company, having been seduced by outsiders, and enjoying it a little too much. Whereas making fun of other people's shoes or Facebook pages is accepted as an authentic narrative for the blog's regular readers, writing about commercial products is considered "vapid" and "superficial." As with Alicia's audience, Carrie's readers do not appreciate the turn that her blog has taken now that she has accepted the role of marketer. They may still find her "cute," but they publicly warn her not to turn into a "walking wallet" whose blog revolves around "artificial" advertisements.

Three months later, Carrie writes about the new sportutility vehicle that her parents have bought and that she loves to drive. Her word choice is almost identical to how she described her feelings for the MobiTech phone. Again, she receives many negative comments, including accusations that her "blog [has] turned into a thinly-veiled advertisement for consumer products" (blog comment November 1, 2006). Carrie defends herself with the following unapologetic response: "See, but the thing is: I buy products. We all buy products. I try to be as honest as possible on this blog and so I share details of what goes on in my life. I can't post about my work to a great extent (confidentiality agreement) and I don't want to reveal the finite details of my personal life (my audience is a tad out of control these days) — so I'm trying to be at least accurate on one front" (blog comment November 1, 2006).

The response we observe is a direct result of the WOMM campaign's presentation conflicting with the narrative established in the blog. Carrie's evolving life project, now marked by both a job and a relationship she values, has transitioned into a period of privacy. Her coming-of-age story is almost over, and she no longer has much titillating material for her voyeuristic audience. Carrie responds to the complaints largely by dismissing them, in a post in which she talks about her blogging activity as "generating content" (blog post August 22, 2006). Unlike Frank and Alicia, who disclose information about themselves to their audiences and inform them about the transitions they are going through, Carrie has created a character based on herself but is now running short on interesting material. The blog's postings gradually decrease from an average of 14 postings per month in 2005 , to 8 per month in 2006 , to only 2 to 3 per month in 2007 and 2008. Comments and readership also steadily decline.

\section{Judith's Blog: Honest Survival and an Honest Living}

Character narrative, forum, and communal orientation. According to her blog, Judith is a married 39-year-old emergency room nurse. However, as her blog tells the story, for two years she has been on sick leave from her job because of various ailments. The blog's personal life crisis narrative combines the tone of a friendly neighbor with that of a frustrated, brassy, no-nonsense woman. It recounts her daily triumphs and foibles, including intimate details of her physical and mental health. Judith's efforts to earn a living in the context of a chronic medical condition create a halo of authenticity that her audience responds to with empathic comments. As with Alicia's blog, the values and goals of Judith's narrative include expressing honesty, being downto-earth, and being caring. Unlike Alicia's blog, however, this narrative makes no secret that Judith's current objective involves surviving and making money where she can.

Judith writes about her medical odyssey in great detail, but having identified blogging as an alternative source of income to her chosen profession, she markets unashamedly on various forum types. On the blog we studied, after a series of invasive tests, Judith posts a photo of a breaking wave titled "Rolling Waves." She does not normally annotate these photographic postings but makes an exception to keep her readers updated on her condition. Yet, even as she reveals her discomfort, she also continues her promotional efforts, focusing her readers' attention on the blogger who is currently "renting" (i.e., advertising on) her Web site:

Just a quick note, the picture above is what my stomach feels like right now. Rolling waves of PAIN. The tests I wrote about in my last post are what is causing that pain or maybe it was preparing for the tests on Sunday. Either way, I'm now the proud owner of a, hopefully, resolving bowel obstruction and I hurt like hell. I'll write more about this later on today. Hopefully I'll be feeling a bit better by then. In the meantime, my poor renter has been neglected. Won't you please go and visit Jerry? (blog post June 29, 2006)

This posting results in 26 comments, among the highest number of responses to a single post in our data set. All are positively inclined toward Judith, and only 5 comments do not explicitly express sympathy for her condition. Notably, many comments explicitly acknowledge her dual identity as both consumer (a woman in chronic pain) and producer (e.g., selling advertising space or product reviews). For example, "Dr. Groovy" writes, "Well, I can't help you medically, as my formal training is in pediatrics, so I will try to 
make you feel better by clicking on your renter." Another commenter simply indicates sympathy by clicking as directed: "BlogMad hit cha ching" (comments posted on Judith's blog June 28, 2006).

Although she establishes her character as a hardworking wife on sick leave trying to pay the bills, Judith has grown her Web activity into a sophisticated cottage industry. Her 12 editorial-style blogs offer regular columns, theme weeks, contests, and recurring features. Judith's narrative reveals a growing astuteness, as she carefully monitors the blogs' statistics, promotes her sites to increase their traffic, and works diligently to profit from them. The narrative also makes clear that Judith views her blog as a product to develop and a brand to maintain, a type of online magazine whose engaging content she develops with readers' suggestions. The blog sells plenty of advertising; it is not uncommon to see more than 25 advertisements surrounding and interjected into her postings. As does Alicia, she also accepts Payperpost assignments.

The WOMM campaign. Judith begins her participation in the Buzzablog campaign with a sophisticated teaser campaign that tempts her readers with a mystery, telling them that she is about to receive something nice. The good news that she has been selected to receive a mystery product is added at the end of a post enumerating a challenging set of circumstances: Her Web site is hacked, she receives her first negative comment, and her television set has broken and requires an expensive repair. Reporting her good fortune in the context of an otherwise debilitating set of events is a rhetorical device used frequently on this blog. It provides a sense of drama to her character narrative and frames the perks she receives as relief rather than entitlement, as Carrie does. Similar to other blog content, the posting about the phone is handled professionally, conceived the way a marketer might design a campaign. Buzzablog and its offer are not dissected. Moral quandaries are not raised. The focus is squarely on the phone and its features.

When Judith's blog reveals the product she has been given, it does so framed in the innocence of summer pastimes. As Judith and her husband stop for what is presented as a well-deserved ice-cream cone, she snaps a picture of the shop's sign with her new phone. The sign reads, "May all your days be ice cream days," and in the 18 comments that result from the post, 16 mention the ice cream and only 2 mention the phone. The readers' comments express delight in her good fortune and share positive comments about the phone. "May all your days be ice cream days too," starts one comment, continuing, "The phone sounds awesome. I have a MobiTech 3839 that I adore. Enjoy" (blog comment July 8, 2006).

Judith's response to the phone is equanimous; for example, her excitement at being selected to receive the product is moderated by her description of the device as "newish." Similarly, she professes enthusiasm for the phone's 1.3 megapixel built-in camera but then notes, "Ok so 1.3 megapixels doesn't compare to the latest digital cameras but I've found that it takes pretty good photos. I can also record up to an hour of video if I want to.... The only problem is that the video is in $3 \mathrm{GP} . .$. . If anyone could give me some suggestions for some conversion software I'd appreciate it" (blog post July 8, 2006).

Over time, as Judith's sick leave continues, her blog becomes increasingly profitable. A year after the MobiTech campaign, a blog post entitled "I've hit the 10,000 dollar mark!" reports on her success. For new viewers of the blog, the post contains a detailed explanation of her WOMM participation:

I started doing paid blogging because I've been off work since December 4th 2005 due to Crohn's. I still have a job as an ER nurse, but I'm unable to perform my duties because I'm simply too ill.... I was getting sick pay and then medical unemployment for a while, but the money ran out by July 2006.... So last October, as our situation started to become desperate I went searching for another way to make money. Something that wouldn't be too hard for me to do. I came across Payperpost and decided to try it. Don't get me wrong-it's not easy work, but it's certainly easier than 12 hour ER nursing shift!... This year I really can see that I could make a living off my websites. (blog post June 15, 2007)

This explanatory post garners 51 comments, all congratulatory. Judith's personal narrative as a Sisyphean figurerepeatedly making progress only to be overwhelmed by illness or ill fate-is reflected in many of the comments, which frame her WOMM activity as heroic. For example, as "Antonella" writes,

Congrats! That is certainly a great accomplishment! My sister also has Crohn's and is finally in remission after a couple years. It is great that you have been able to ... make money while dealing with your health. Good luck with meeting your goals, I'm sure you won't have any problem getting there and beyond! (blog comment August 13, 2007)

\section{Summary of Findings}

As the WOMM campaign is incorporated into the publicly displayed character narratives of bloggers such as Frank, Alicia, Carrie, and Judith, among others (see Table 1), we find that a complex pattern emerges. The character narrative forms the backbone of blog content and contains the recollection, development, and representation of more short-term "life projects" and longer-term "life themes" (McCracken 1987; Mick and Buhl 1992; Schau and Gilly 2003) related to lifelong goal pursuits that are commonly called "identity projects" (e.g., Thompson 2005; Thompson and Tambyah 1999).

Each blog contains a particular history and perspective in its character narrative; this narrative attracts a certain audience and plays a part in setting the audience's expectations. Importantly, in each case, the character narrative transforms the substance and form of the WOMM campaign. In addition, we observe explicit differences in the way that members of the online communities respond to the WOMM campaign. This suggests that there is a larger discourse taking place about WOMM campaigns in general, including their rules and ethical implications.

We find that the bloggers and community members are simultaneously flattered and threatened to be selected as WOMM campaign participants. Bloggers are faced with the 
new paradox that results from being recruited as a type of marketer, and the resulting dual role of consumer-marketer colors the way blog narratives present their involvement in the campaign. This dual role is particular to WOMM and the network coproduction model we developed.

Some bloggers attempt to share their good fortune; others write as if they are entitled to receive this honor. Still others analyze WOMM as an important development in blogging or explain their recruitment as a lucky opportunity in light of their dire need. However, as they write about the product and the WOMM campaign that supports it, the bloggers cannot ignore that WOMM has intruded into their discursive domain, transforming interpersonal communications into an intended persuasion effort. It is to these characteristics of the WOMM campaign and their implications for our theoretical understanding of the phenomenon that we now turn.

\section{Narrative Response Strategies Associated with WOMM}

\section{Adherence to Communal Versus Commercial Norms}

Word-of-mouth marketing is based on the assumption that marketers can harness the credibility of consumer-toconsumer WOM. The role of identity in online WOM has been studied frequently (Dellarocas 2003; Forman, Ghose, and Wiesenfeld 2008; Wang and Fesenmaier 2003), with generally mixed results, because many online communities previously allowed and even emphasized varying degrees of anonymity. Yet newer forums of online community, such as social networking sites, emphasize ongoing contact with familiar participants.

Our findings indicate that identifying with and adhering to "communal norms" is critical for a consumer to "evaluate a reviewer" (Forman, Ghose, and Wiesenfeld 2008, p. 311). Rettberg (2008) suggests that blogs constitute a social network that is not only about the sharing of information but also about building trust, friendship, and alliances. Over time, the practices that come to conventionalize information exchange, such as the length of posts or the use of photos, form the basis of more extensive and implicit social norms. Bloggers are expected to conform to those communal norms and to post messages appropriate to their forums. However, as Kozinets (2002, p. 22) notes, broader social tensions are evoked when marketplace relationships mix with communal cultures: "As the self-interested logics of the market have filtered into communal relations, they have been accused of increasingly undermining the realization of the sharing, caring communal ideal."

Many researchers have written about the increasingly intertwined or embedded nature of commercial logic and social relationships (Frenzen and Davis 1990; Grayson 2007; Marcoux 2009; Muñiz and O'Guinn 2001; Price and Arnould 1999; Schau, Muñiz, and Arnould 2009), and this is demonstrated throughout our findings as an inherent challenge associated by definition with all community-oriented WOMM. A tension shapes the varieties of WOMM response, and the source of the conflict is the dual role of the communicator. The communicator-in this article, the blogger-is asked to act both as a continuing community member and as a marketing agent. Prior marketing theories that psychologically account for consumers' resistance are based on a view of marketers who clearly and directly seek to influence the attitudes and purchases of consumers (e.g., Friestad and Wright 1994). Yet in WOMM, in which the consumer is required to be a type of consumer-marketer hybrid, the traditional social contract that maintains marketplace relationships at a distance from communities is violated, creating great tension.

As a result of this tension, we find that WOM communicators invariably take WOMM messages and meanings and then alter them to make the marketing message more believable, relevant, or palatable to the community. Our findings suggest a set of theoretical propositions in which successful WOMM depends on this transformation from persuasionoriented, market-generated, sales objective-oriented "hype" to relevant, useful, communally desirable social information that builds individual reputations and group relationships. In this transformation of a market narrative into a social one, the WOM communicator performs three services valuable to the marketers: (1) communicating the marketing message, (2) staking his or her reputation and trust relationships on the marketing message, and (3) converting the marketing message - through language, substance, or tone- to conform to the norms and expectations the community has developed. Prior research has tended to focus almost exclusively on the first role, namely, message spreading. Less often has it considered the second role, and rarer still is the cultural focus on the third. Yet, by understanding the patterns behind the narrative transformation of marketing messages, we gain increased understanding of and ability to manage WOM.

\section{Descriptions of Factors and Narrative Strategies}

Why do WOMM blog posts take the form that they do, and what does this tell us about WOMM? The answer to these questions lies in the interaction of the community-level factors of narrative, forum, norms, and promotional elements manifest in two other narrative elements: (1) the interpersonal orientation of the WOM communications and (2) its adaptation or acknowledgment of the commercial-communal tension associated with WOMM. Although the outcomes are complex and underdetermined, commercial-communal tension requires a response at this individual level of character narrative, and this response assumes a particular structure depending on other important characteristics of the medium. To maintain a trustworthy relationship with other community members, WOMM communicators balance promotional messages with the need to exhibit a consistent character narrative and to conform to forum standards and communal norms. Again, because WOMM is based on the belief that marketers can harness the inherent credibility of consumer-to-consumer communication, understanding this dynamic, and particularly the need to balance commercialcommunal tensions, is critical for successful practice.

As Figure 3 illustrates, we find in our data a pattern of four different types of communication strategies. First, we have a narrative strategy, exemplified by the blogs of Alicia, 
FIGURE 3

Narrative Strategies for the Communal Reference Expression of WOMM

\begin{tabular}{|c|c|c|}
\hline & $\begin{array}{c}\text { Evaluation } \\
\text { (e.g., Alicia, Joseph, Jasper) }\end{array}$ & $\begin{array}{c}\text { Explanation } \\
\text { (e.g., Frank, Sammy, Randy) }\end{array}$ \\
\hline Communal & $\begin{array}{l}\text { Communication Strategies } \\
\text { - Concealment: minimizes or avoids mention of } \\
\text { WOMM campaign and their participation. } \\
\text { - Product focus: focus on product itself, rather than } \\
\text { WOMM campaign. } \\
\text { - Communal acknowledgment: proactively asserts } \\
\text { communal orientation. } \\
\text { - Leadership: asserts or affirms membership in the } \\
\text { community while positioning as safe or preferred } \\
\text { information source. } \\
\text { Community Reaction } \\
\text { - Negative regarding WOMM campaign, due to } \\
\text { avoidance of campaign's moral issues, dependent } \\
\text { on forum and communal norms. } \\
\text { - Hostility toward opinion leader role, dependent on } \\
\text { congruity with communicator narrative, forum and } \\
\text { norms. }\end{array}$ & $\begin{array}{l}\text { Communication Strategies } \\
\text {-Disclosure: explicitly reveals WOMM campaign } \\
\text { and their participation. } \\
\text {-Awareness of cultural tension: explicitly signals } \\
\text { awareness of cultural tension between WOM } \\
\text { marketing goals and community orientation. } \\
\text { - Communal acknowledgment: proactively asserts } \\
\text { communal orientation. } \\
\text { - Leadership: asserts or affirms membership in the } \\
\text { community while positioning as safe or preferred } \\
\text { information source. } \\
\text { Community Reaction } \\
\text {-Supportive or neutral regarding WOMM campaign. } \\
\text {-Acceptance of opinion leader role, dependent on } \\
\text { forum and communal norms. }\end{array}$ \\
\hline Communications & $\begin{array}{c}\text { Embracing } \\
\text { (e.g., Carrie, Franklin, Svetlana) }\end{array}$ & $\begin{array}{c}\text { Endorsement } \\
\text { (e.g., Judith, Troy, Shane) }\end{array}$ \\
\hline Individualistic & $\begin{array}{l}\text { Communication Strategies } \\
\text {-Acceptance: consumer-marketer dual role } \\
\text { enthusiastically adopted. } \\
\text { - Justification: personal needs emphasized over } \\
\text { community needs, in terms of privilege or equity. } \\
\text { - Professionalization: promotional marketing } \\
\text { language and terms used; additional marketing } \\
\text { opportunities requested. } \\
\text { Community Reaction } \\
\text { - Mixed, polarized responses. } \\
\text { - Negative regarding WOMM campaign if not } \\
\text { related to prior forum content and communicator } \\
\text { narrative. } \\
\text { - Positive if communal norms, forum, and } \\
\text { communicator narrative are congruent with } \\
\text { WOMM campaign. } \\
\text { - Resistance to opinion leader role, dependent on } \\
\text { congruity. }\end{array}$ & $\begin{array}{l}\text { Communication Strategies } \\
\text { •Disclosure: explicitly reveals WOMM campaign } \\
\text { and their participation. } \\
\text { •Awareness of cultural tension: explicitly signals } \\
\text { awareness of cultural tension between WOM } \\
\text { marketing goals and community orientation. } \\
\text { - Justification: personal needs emphasized over } \\
\text { community needs, in terms of privilege or equity. } \\
\text {-Professionalization: promotional marketing } \\
\text { language and terms used; additional marketing } \\
\text { opportunities requested. } \\
\text { Community Reaction } \\
\text {-Tempered negative regarding WOMM campaign. } \\
\text {-Support for opinion leader role, dependent on } \\
\text { whether narrative is deemed "deserving," if } \\
\text { narrative integrates WOMM campaign, and if } \\
\text { communal norms are supported. }\end{array}$ \\
\hline & \multicolumn{2}{|c|}{$\begin{array}{c}\text { Commercial- } \\
\text { Cultural } \\
\text { Tension }\end{array}$} \\
\hline
\end{tabular}

Jasper, and Joseph, that we call evaluation. The evaluation strategy deals with cultural anxiety by avoiding it; the WOMM campaign is minimized through concealment, and attention is drawn to the good or service rather than to the marketing campaign. This WOM strategy is aimed at retaining affiliation with bloggers' audiences through acknowledgment of their communities' needs and goals. Communicators affirm their leadership position by attempting to demonstrate that their information and opinions are trustworthy. Yet, in ignoring the moral tension inherent in WOMM, the evaluative strategy can backfire, generating reader-blogger tension. The community attempts to reconcile the question of why one of its members would deemphasize or obscure their other interests and may read the source as having ulterior motives. This disparity, coupled with the apparent incongruity of the blogger benefiting at the individual level while professing a communal orientation, can result in explicit hostility.

Second, there is the "embracing" strategy, which is evident in the blogs of Carrie, Franklin, and Svetlana. Their narratives also keep the cultural anxiety implicit, but they mention the WOMM campaign and their participation in it, 
using terms of enthusiastic acceptance. These narratives offer a bold, self-interested justification alongside their open adoption of the dual role as a consumer and marketer. The embracing strategy adopts the professional language and terms of marketing and also often includes requests for further opportunities to promote other products. Our findings indicate polarized communal responses to this strategy. Some find the honesty and self-interest refreshing, particularly when it fits well with the existing narrative, forum, and norms. However, there were also many unfavorable responses, particularly when elements of the WOMM promotions-for example, its exclusivity-were not congruent with prior narrative themes, such as those of friendliness and inclusion. In these cases, the trustworthiness of the communicator was often called into question.

Third, the blog narratives of Judith, Troy, and Shane demonstrate the "endorsement" strategy. In this communication approach, bloggers express and acknowledge the commercial-communal tension through a strategy of disclosure of the WOMM campaign and their participation in it. Furthermore, their narratives signal an awareness of marketers' intentions and acknowledge that they may not be in the best interests of the community. However, they also attempt to discharge these concerns with a justifying argument of need. An individualistic orientation is adopted in which the communicator argues for his or her own selfinterest, often through a communal appeal for assistance, support, and understanding. These bloggers also adopt a professionalized promotional language and signal a willingness to favor other marketing requests. In our data, this type of strategy does not seem to arouse hostility in blogs-such as Judith's - that are able to connect emotionally with community members. In other blogs, in which the narratives were less convincing and/or the communal norms were violated, these appeals have been much less successfully received.

Fourth, the blog narratives of Frank, Sammy, and Randy exemplify the most open and communal WOMM communications strategy, which we call "explanation." In the explanation strategy, the narratives openly disclose the presence of the WOMM campaign and analyze the various communal impacts of participation in it. The bloggers explicitly acknowledge and discuss the potential conflict of interest associated with WOMM, but they do so while asserting the importance and interests of their communities in a manner that affirms their own value to the community as a safe or preferred source of information. In this way, the communicator demonstrates continued shared affiliation with other members in the community and presents the WOMM campaign in a way that might even lead to the strengthening of communal ties. Community members were either positive or neutral regarding the WOMM campaign, whose characteristics and pros and cons had already been carefully analyzed and democratically discussed.

In general, we find that the intrusion of commercial "hype" presents a type of moral hazard when it contains the inappropriate and unsanctioned mixing of dominant norms, such as sharing, caring, or market exchange. Word-ofmouth marketing communicators are tempted to assume dual and potentially inappropriate roles. Our results suggest that the potential communal disruptions of WOMM follow a discernable pattern that we can now proceed to elaborate.

In contexts in which communal norms are accepting or favorable toward the marketplace - as they are in many brand communities, consumer tribes, and fan gatherings, as well as in many larger, for-profit, or commercially sponsored communities-embracing and endorsing strategies are viewed favorably. Because these communities' norms are supportive of commercialism and consumerism, audiences expect these narratives and respond favorably. Alternatively, communities whose norms are resistant to profit motives and the logics of the marketplace - such as those that are particularly tight-knit or secretive, personable, local, and "caring and sharing"-resist the blatant commercialism and self-promotion of an embracing strategy that threatens their norms. Expectations are communally centered and not marketplace related or even individualistically driven. We find that these communities respond much more favorably to the explicit explanation narrative.

The communications forum is another important factor influencing WOM narrative and communal response. Not surprisingly, when the forum involves an inherent vulnerability or intimacy on the part of the communicator, such as the inevitable disclosures that accompany the chronicling of an illness, the audience's resulting support and sympathy provide latitude for a successful explanation or endorsement strategy. Alternatively, when the communications forum is less personal-for example, one that primarily provides lifestyle or entertainment content-the audience may be more likely to respond well to the commercial narrative of the embracing strategy. Similarly, if the forum tends to be a site driven by technical information, the forum's audience expects an evaluation narrative and, accordingly, responds positively.

As we have demonstrated in our analysis of blogger scenarios, communicators establish particular types of narrative styles that can be interpreted as enacting particular character types. Each character type requires a specific performance of the blogging practice (Reckwitz 2002) that consists of certain behaviors, understandings, and emotions that are socially constructed and communally understood (Schau, Muñiz, and Arnould 2009). Subject to the influence of other factors identified in our model, these established character types are likely to yield particular responses to WOMM promotions because the communicator seeks a consistent representation that conforms to the practices he or she has established with the audience. Thus, we observe how a conscientious citizen journalist and community newcomer manifests a thoughtful explanation strategy; how a humble mother who "tells it like it is" encounters friction using an outspoken evaluation strategy; how a narcissistic, self-proclaimed expert expresses WOMM by assuming an embracing strategy; and how a sympathetic, "making-endsmeet" professional blogger successfully employs an endorsement strategy.

Finally, the type of WOMM promotion, including the product type, must be considered. Technology and other high-involvement products would tend to naturally inspire more evaluation, while fashion and entertainment products result in more embracing narratives. Because of their 
explicit commercialism, hard-sell offers result in more explanation and evaluation, while soft-sell, long-term brand-building campaigns, such as funny, viral, or embedded advertising created to be spread rapidly among large numbers, inspire endorsing or embracing narratives (if any). Word-of-mouth marketing programs that overtly seek recommendations, mentions, or reviews may encourage narrative responses using the evaluation strategy.

\section{Theoretical Implications}

Consumers who communicate marketing messages to other consumers were previously assumed to engage in this behavior as a result of altruism or reciprocity or to attain higher status (Dichter 1966; Engel, Kegerreis, and Blackwell 1969; Gatignon and Robertson 1986). Our investigation reveals something else. Motivations to participate in the bold new world of network coproduction of WOM are more complex and culturally embedded, shaped by communal interests and communicative orientations and charged with moral hazard. Along with previously identified factors, such as personality and general communal involvement (Wang and Fesenmaier 2003) or desire for social interaction or economic incentives (Hennig-Thurau et al. 2004; Wang et al. 2007), WOM communicators in our research demonstrate their need to balance inherent commercial-communal tensions while being consistent with the character elements of their ongoing narrative. These findings also question Brown, Broderick, and Lee's (2007) suggestion that a Web site, rather than a person, is viewed as the primary actor in online WOM. Similar to Wang and colleagues' (2007) online retailer avatars, relationships in blogging communities are personal. However, as our research reveals, WOM communicators who garner positive responses are not simply personal, they are personal in a communally appropriate manner.

Our findings generate several propositions for further verification and testing. We find that WOMM messages and their attendant meanings will be altered by communicators in ways that are attuned to a range of different individual and communal factors. We determine that character narratives, communications forums, and communal norms are key elements interacting with the WOMM promotion to manifest particular forms of WOM narrative. This research identifies four distinct strategic patterns that communicators use: evaluation, embracing, endorsement, and explanation. Our analysis of reader comments and responses suggests that a positive communal attitude toward a WOMM message will be a function of the way that it (1) is consistent with the goals, context, and history of the communicator's character narrative and the communications forum, or media; (2) acknowledges and successfully discharges commercialcommunal tensions or offers a strong reason an individualistic orientation is suitable; and (3) fits with the community's norms and is relevant to its objectives.

Word-of-mouth marketing operates through a complex process that transforms commercial information into cultural stories relevant to the members of particular communities. This research explores this process in only one limited context (i.e., the online context) and for only one marketing campaign, doing so at a time when this form of marketing was still novel and focusing our data collection almost exclusively on textual data rather than, for example, photographic, graphical, or audiovisual data. These limitations also lead to opportunities. Research that examines the WOMM phenomenon in different and new contexts, both online and off, across, for example, social networking sites and in-home parties, using combinations of advanced visual and textual analysis, will help further our understanding and guide our management of this increasingly important form of marketing.

\section{Managerial Implications}

This research offers several practical suggestions for managers and marketers employing WOMM campaigns and techniques across all forums, not only online. Our major findings question marketers' fundamental assumptions regarding WOM, represented by the common use of terms such as "amplification" to discuss marketing's impact on WOM. Amplification assumes a simple quantitative increase in frequency of an intact marketing message, similar to increasing gross rating points on ad spending. Indeed, as our interview with Buzzablog's manager suggested, positive blogger mentions were interpreted as key indicators of the success of this campaign. However, our model suggests that a particular WOMM promotion must be presented in a manner that is congruent with the ongoing character narrative, communications forum, and communal norms prevalent in that WOM environment. This theory draws managerial attention to the importance of working with a deep knowledge and awareness of the network coproduction of marketing messages and meanings through consumer-generated narratives.

Measurement and classification of the different types of character narratives and communications forums available to marketers is a necessary first step to the implementation of this understanding. For example, we discussed several character narratives, providing a rudimentary classification of blogger archetypes: the citizen journalist, the tell-it-likeit-is mother, the satirical exhibitionist, the making-endsmeet professional blogger, and so on. There are undoubtedly many other character types that managers should explore, classify, and develop, not only across blogs or online communities but also across all media. Similarly, we discussed communications forums as belonging to particular types: the technology forum, the mommy forum, the relationship forum, the personal life crisis forum, and so on. Each of these forums responds to and fits into preexisting narrative expectations on the part of the audience, while accommodating the need for complexity and variety through hybridized forms.

Understanding and respecting communal norms is also important. Although this research focused on one particular dimension - the resistance and acceptance of commercial values - a range of other norms and values could be explored, classified, and related to particular outcomes, such as reciprocity, trust, or the role of authority. Depending on the context, including the product being marketed and 
the target market, managers should proactively explore the norms associated with the respective communication forum.

Finally, we explored a WOMM campaign that had specific characteristics, including the stipulation that bloggers were not mandated to blog about the seeded product, they were allowed to include positive and/or negative comments, and the manufacturer and marketing agency were open to disclosure. Managers should consider carefully the implications associated with these types of details, particularly their impact on commercial-communal tensions. Many other types of campaigns are possible, and the classification and theoretical understanding of each over time through research and practice will lead to improved effectiveness.

Importantly, our research results suggest that managers have an opportunity to encourage particular narrative strategies that may be ideal for their product and/or their campaign. Managers should begin to work with an understanding of WOMM's cultural complexity by seeking to foster and develop particular kinds of WOM narrative strategies that are congruent with particular communicator character types and community norms and practices. Evaluation and explanation narratives are congruent with communally oriented communicators who are part of "caring and sharing" communities. Alternatively, an embracing or endorsement narrative fits with an individualist communicator participating in a community favorable toward the marketplace. Finally, managers need to attune the type of WOMM promotion form itself to the characteristics of the WOM environment. Hard-sell offers would lend themselves to narrative strategies of explanation and evaluation, while embracing and endorsing narratives would be congruent with soft-sell, long-term brand-building campaigns.

Our findings complicate the current prediction and measurement of WOMM success. Common sense may encourage managers to amplify positive and minimize negative WOM regarding their products. However, recent research, including ours, highlights that successful WOMM campaigns may embody more than a simple abundance of positive mentions. Sometimes, WOMM communicators include negative information, perhaps partially to negotiate cultural tension or, as Schlosser (2005) contends, to enhance their credibility. Liu (2006) argues that the volume of online WOM mentions, rather than their positive or negative valence, best predicts product success. However, the narrative strategies of evaluation, embracing, endorsement, and explanation offer different ways of understanding process and outcomes than positive or negative mentions. They portray a multidimensional process of personal and communal storytelling, an ongoing conversation that WOMM simultaneously facilitates and interrupts. They suggest that mentions are not all created equal, and therefore appreciation for the cultural side of this process and understanding of its particular elements will likely lead to more sophisticated assessment of the narrative outputs of these campaigns. These changes are already beginning, as forward-looking marketers (such as those at Buzzablog and MobiTech) are already assessing engagement, persuasion, and interaction instead of measuring simple raw impressions. Furthermore, there is an opportunity for marketing managers to focus on the valuable qualitative insights that emerge from such online WOMM programs. Because blogs and other social media forums constitute a (semi)permanent archive of consumers' WOM, managers can mine the conversations for consumer insights into their products and even into their marketing programs.

Whether conducted online or offline, WOMM should be viewed as an inextricable form of marketing that includes such fashionable-but, we believe, relevant-concepts and terms as prosumers, open-source marketing (Pitt et al. 2006), Wikinomics (Tapscott and Williams 2006), brand communities (Fournier and Lee 2009; McAlexander, Schouten, and Koening 2002; Muñiz and O'Guinn 2001), and consumer tribes (Cova, Kozinets, and Shankar 2007). Marketing management is just beginning to adapt to this new age of the networked coproduction of marketing messages and meanings, a notion that has become increasingly evident to managers in radically altered industries, such as advertising, music production, and newspaper publishing. As it becomes increasingly recognized that few industries will remain untouched, we will increasingly understand how to supplement broadcasting of hypercommercial messages with the careful cultivation of consumers' narrative networks.

\section{REFERENCES}

Arndt, Johan (1967), "Role of Product-Related Conversations in the Diffusion of a New Product," Journal of Marketing Research, 4 (August), 291-95.

Balter, Dave (2005), Grapevine. New York: Portfolio.

Bass, Frank M. (1969), "A New Product Growth Model for Consumer Durables," Management Science, 15 (5), 215-27.

Brooks, Robert C., Jr. (1957), “'Word of Mouth' Advertising in Selling New Products,” Journal of Marketing, 22 (October), 154-61.

Brown, Jo, Amanda Broderick, and Nick Lee (2007), "Extending Social Network Theory to Conceptualise On-Line Word-ofMouth Communication," Journal of Interactive Marketing, 21 (3), 2-19.

Brown, Stephen, Robert V. Kozinets, and John F. Sherry Jr. (2003), "Teaching Old Brands New Tricks: Retro Branding and the Revival of Brand Meaning," Journal of Marketing, 67 (July), 19-33.
Cova, Bernard (1997), "Community and Consumption: Towards a Definition of the Linking Value of Products or Services," European Journal of Marketing, 31 (3-4), 297-316.

_ and Veronique Cova (2002), "Tribal Marketing: The Tribalisation of Society and Its Impact on the Conduct of Marketing," European Journal of Marketing, 36 (5-6), 595-620.

— Tribes. Oxford: Butterworth-Heinemann.

Dellarocas, Chrysanthos (2003), "The Digitization of Word of Mouth: Promise and Challenges of Online Feedback Mechanisms," Management Science, 49 (October), 1407-1424.

Dichter, Ernest (1966), "How Word-of-Mouth Advertising Works," Harvard Business Review, 16 (November-December), 147-66.

Engel, James F., Robert J. Kegerreis, and Roger D. Blackwell (1969), "Word-of-Mouth Communication by the Innovator," Journal of Marketing, 33 (July), 15-19. 
Feick, Lawrence F. and Linda L. Price (1987), "The Market Maven: A Diffuser of Marketplace Information," Journal of Marketing, 51 (January), 83-97.

Forman, Chris, Anindya Ghose, and Batia Wiesenfeld (2008), "Examining the Relationship Between Reviews and Sales: The Role of Reviewer Identity Disclosure in Electronic Markets," Information Systems Research, 19 (September), 291-313.

Fournier, Susan and Lara Lee (2009), "Getting Brand Communities Right," Harvard Business Review, (April), 105-111.

Frenzen, Jonathan K. and Harry L. Davis (1990), "Purchasing Behavior in Embedded Markets," Journal of Consumer Research, 17 (June), 1-12.

Friestad, Marian and Peter Wright (1994), "The Persuasion Knowledge Model: How People Cope with Persuasion Attempts," Journal of Consumer Research, 21 (1), 1-31.

Gatignon, Hubert and Thomas S. Robertson (1986), "An Exchange Theory Model of Interpersonal Communication," in Advances in Consumer Research, Vol. 13, Richard J. Lutz, ed. Provo, UT: Association for Consumer Research, 534-38.

Godes, David, Dina Mayzlin, Yubo Chen, Sanjiv Das, Chrysanthos Dellarocas, Bruce Pfeffer, et al. (2005), "The Firm's Management of Social Interactions," Marketing Letters, 6 (3-4), $415-28$

Gould, Emily (2008), "Exposed," New York Times Magazine, (May 25), (accessed October 27, 2009), [available at http:// www.nytimes.com/2008/05/25/magazine/25internet-t.html].

Grayson, Kent (2007), "Friendship Versus Business in Marketing Relationships," Journal of Marketing, 71 (October), 121-39.

Hennig-Thurau, Thorsten, Kevin P. Gwinner, Gianfranco Walsh, and Dwayne D. Gremler (2004), "Electronic Word-of-Mouth via Consumer-Opinion Platforms: What Motivates Consumers to Articulate Themselves on the Internet?" Journal of Interactive Marketing, 18 (1), 38-52.

Hoffman, Donna L. and Thomas P. Novak (1996), "Marketing in Hypermedia Computer-Mediated Environments: Conceptual Foundations," Journal of Marketing, 60 (July), 50-68.

Holbrook, Morris B. (2001), "The Millennial Consumer Enters the Age of Exhibitionism. A Book Review Essay: Part 1," Consumption, Markets and Culture, 4 (4), 383-437.

Holt, Douglas B. (2002), "Why Do Brands Cause Trouble? A Dialectical Theory of Consumer Culture and Branding," Journal of Consumer Research, 29 (June), 70-88.

Jaffe, Joseph (2007), Join the Conversation: How to Engage Marketing-Weary Consumers with the Power of Community, Dialogue and Partnership. New York: John Wiley \& Sons.

Katz, Elihu and Paul F. Lazarsfeld (1955), Personal Influence. New York: The Free Press.

Kelly, Lois (2007), Beyond Buzz: The Next Generation of Word-ofMouth Marketing. New York: AMACOM.

King, Charles W. and Frank O. Summers (1976), "Overlap of Opinion Leadership Across Product Categories," Journal of Marketing Research, 7 (February), 43-50.

Kozinets, Robert V. (2001), "Utopian Enterprise: Articulating the Meanings of Star Trek's Culture of Consumption," Journal of Consumer Research, 28 (June), 67-88.

— (2002), "The Field Behind the Screen: Using Netnography for Marketing Research in Online Communities," Journal of Marketing Research, 39 (February), 61-72.

- (2007), "Netnography 2.0," in Handbook of Qualitative Research Methods in Marketing, Russell W. Belk, ed. Cheltenham, UK: Edward Elgar Publishing, 129-42.

Kutchera, Joe (2008), "Navigate the Blogosphere's Biggest Ad Networks," iMedia Connection, (accessed November 14, 2008), [available at http://www.imediaconnection.com/content/20486. asp].

Liu, Yong (2006), "Word of Mouth for Movies: Its Dynamics and Impact on Box Office Revenue," Journal of Marketing, 70 (July), 74-89.
Marcoux, Jean-Sébastien (2009), "Escaping the Gift Economy," Journal of Consumer Research, 36 (4), 671-85.

McAlexander, James H., John W. Schouten, and Harold F. Koening (2002), "Building Brand Community," Journal of Marketing, 66 (January), 38-54.

McCracken, Grant (1987), "Advertising: Meaning or Information," in Advances in Consumer Research, Vol. 14, Melanie Wallendorf and Paul Anderson, eds. Provo, UT: Association for Consumer Research, 121-24.

Mick, David Glen and Claus Buhl (1992), "A Meaning-Based Model of Advertising Experiences," Journal of Consumer Research, 19 (3), 317-38.

Muñiz, Albert M. and Thomas C. O'Guinn (2001), "Brand Community," Journal of Consumer Research, 27 (4), 412-32.

- and Hope Jensen Schau (2005), "Religiosity in the Abandoned Apple Newton Brand Community," Journal of Consumer Research, 31 (4), 737-47.

Nussbaum, Emily (2004), "My So-Called Blog," New York Times Magazine, (January 11), (accessed October 2009), [available at http://www.nytimes.com/2004/01/11/magazine/11BLOG.html].

Pitt, Leyland F., Richard T. Watson, Pierre Berthon, Donald Wynn, and George Zinkhan (2006), "The Penguin's Window: Corporate Brands from an Open-Source Perspective," Journal of the Academy of Marketing Science, 34 (2), 115-27.

PQ Media (2009), "Exclusive PQ Media Research: Despite Worst Recession in Decades, Brands Increased Spending on Word-ofMouth Marketing 14.2\% to \$1.54 Billion in 2008," (accessed October 30, 2009), [available at http://www.pqmedia.com/ about-press-20090729-wommf.html].

Price, Linda L. and Eric J. Arnould (1999), "Commercial Friendships: Service Provider-Client Relationships in Context," Journal of Marketing, 63 (October), 38-56.

Reckwitz, Andreas (2002), "Towards a Theory of Social Practices: A Development in Culturalist Theorizing," European Journal of Social Theory, 5 (2), 243-63.

Rettberg, Jill Walker (2008), Blogging. Cambridge, UK: Polity.

Rogers, Everett M. (1962), The Diffusion of Innovations. New York: The Free Press.

Rosen, Emanuel (2009), The Anatomy of Buzz Revisited. New York: Doubleday Business.

Ryan, B. and N.C. Gross (1943), "The Diffusion of Hybrid Seed Corn in Two Iowa Communities," Rural Sociology, 8 (March), $15-24$.

Schau, Hope Jensen and Mary C. Gilly (2003), "We Are What We Post? Self-Presentation in Personal Web Space," Journal of Consumer Research, 30 (December), 385-404.

, Albert M. Muñiz Jr., and Eric Arnould (2009), "How Brand Community Practices Create Value," Journal of Marketing, 73 (September), 30-51.

Schlosser, Ann E. (2005), "Posting Versus Lurking: Communicating in a Multiple Audience Context," Journal of Consumer Research, 32 (September), 260-65.

Sernovitz, Andy (2006), Word of Mouth Marketing: How Smart Companies Get People Talking. Chicago: Kaplan Business Publishing.

Tapscott, Don and Anthony D. Williams (2008), Wikinomics: How Mass Collaboration Changes Everything. New York: Penguin.

Thompson, Craig J. (2005), "Consumer Risk Perceptions in a Community of Reflexive Doubt," Journal of Consumer Research, 32 (2), 235-48.

__ (1997), "Interpreting Consumers: A Hermeneutical Framework for Deriving Marketing Insights from the Texts of Consumers' Consumption Stories," Journal of Consumer Research, 34 (November), 438-55.

— and Siok Kuan Tambyah (1999), "Trying to be Cosmopolitan," Journal of Consumer Research, 26 (3), 214-41.

Thompson, Scott A. and Rajiv K. Sinha (2008), "Brand Communities and New Product Adoption: The Influence and Limits of 
Oppositional Loyalty," Journal of Marketing, 72 (November), 65-80.

USC Annenberg School (2008), The Digital Future Report. Los Angeles: USC Annenberg School.

Vargo, Stephen L. and Robert F. Lusch (2004), "Evolving to a New Dominant Logic for Marketing," Journal of Marketing, 68 (January), 1-17.
Wang, Liz C., Julie Baker, Judy A. Wagner, and Kirk Wakefield (2007), "Can a Retail Web Site Be Social?" Journal of Marketing, 71 (July), 143-57.

Wang, Youcheng and Daniel R. Fesenmaier (2003), “Assessing Motivation of Contribution in Online Communities: An Empirical Investigation of an Online Travel Community," Electronic Markets, 13 (January), 33-45.

Whyte, William H., Jr. (1954), "The Web of Word of Mouth," Fortune, 50 (November), 140-43. 
Copyright of Journal of Marketing is the property of American Marketing Association and its content may not be copied or emailed to multiple sites or posted to a listserv without the copyright holder's express written permission. However, users may print, download, or email articles for individual use. 